\title{
First steps in forecasting the health workforce in Kazakhstan: A baseline scenario
}

\author{
Azamat Kharin, Berik Koichubekov, Bauyrzhan Omarkulov, Marina Sorokina, Ilya Korshukov, Nazgul \\ Omarbekova
}

Department of Informatics and Biostatistics, Karaganda Medical University, Karaganda city, Republic of Kazakhstan

Received: 2021-03-18.

Accepted: 2021-05-28

This work is licensed under a Creative Commons Attribution 4.0 International License

J Clin Med Kaz 2021; 18(3):40-45

Corresponding author: Berik Koichubekov.

E-mail: koychubekov@kgmu.kz; ORCID: 0000-0002-8030-5407

\section{Abstract}

Background: The purpose of this study was to consider the basic scenario for predicting the need for general practitioners in Kazakhstan until 2030.

Material and methods: A basic health care human resource planning model consists of supply and demand components, analysis of the outcomes of the prediction, and planning future actions. Stock-flow consistent model was built by using current situation and projected Kazakhstan population, retirement rate, attrition rate and adding the estimated number of new graduates.

Results: According to the proposed scenario, in some years of the forecast period, both an excess and a lack of a general practitioners offer are possible. The largest surplus, 226 doctors, is predicted in 2024. However, starting in 2027 their shortage is possible, with a peak of 339 general practitioners in 2030.

Conclusion: Considered scenario leads to the fact that inflow does not cover the increasing needs of primary health care associated with population growth. In this case, our forecast is the basis for medical schools to adjust the number of general practitioners students in internship, seeking a balance of supply and demand.

Key words: human resources forecasting, health care workforce, workforce planning, public health

\section{Introduction}

At present, the World Health Organization and many countries of the world pay great attention to the problems of health care workforce planning [1]. Health workforce planning involves assessing demands and supplies, correctly resources distribution, and making plans to address potential imbalances [2].

The involvement of a wide range of stakeholders in the human resources planning process, especially in the discussion of the modeling itself, has an overall impact on human resources for health policy, as it increases the engagement of various stakeholders and encourages them to engage in dialogue. This leads to the fact that health policy is not developed by a narrow circle of people, but takes into account the views of various interested sectors of society. This interaction opens up new trends in this area and develops new ideological approaches to healthcare [3].

Approaches commonly used to predict future human resources for health care (HRH) include: population ratio method [4], health need method [5], health demand method
[6], service target-based approaches [5]. According to Dresh N. and his colleagues each of these approaches has its advantages and disadvantages [7].

Basically, health care human resource planning model consists of supply and requirement components, analysis of the outcomes of the prediction, and planning future actions, or in simpler terms, analysis of supply, demand, gap and solution $[8,9]$.

In the process of planning and modeling of medical personnel, it is necessary to take into account the following aspects: components that make up demand and supply, methods of their assessment, an algorithm for combining them, initial conditions and assumptions, changes in parameters over time, possible development scenarios (one or more) [10].

Typically, most planning systems consider more than one scenario - a baseline scenario and one or more alternative scenarios. The health workforce projection model can create different scenarios, taking into account possible changes in the socio-economic, epidemiological and demographic situation in the country, as well as 
changes in health policy. The developed scenarios differ depending on the profession and the purpose of forecasting.

The Republic of Kazakhstan occupies a vast territory of 2724902 sq. km., while the population density is extremely low (6.51 people per sq. $\mathrm{km}$ ). Different regional administrative subdivisions (central, northern, eastern, southern and western) differ in the level of socio-economic development, population density, climatic conditions and the degree of urbanization. Like other countries of the world, Kazakhstan suffers from a geographically uneven distribution of human resources for health. In all regions, except megacities, there is a shortage of medical workforce. The approaches to HRH forecasting and planning used until recently were ineffective. Human resource planning has historically not been a priority for health policy implemented by local health authorities. There is guideline "Methods of planning and forecasting human resources for health care" on the website of the Republican Center for Health Development [11]. In addition to simple models based on population size and service targets, the authors propose a regression model that includes demographic, sociocultural, and epidemiological factors. However, this planning tool can best be classified as a demand-based model - there is no supply side and it do not measure expected balance between the required and available number of health professionals for the next years. The disadvantages of linear models include the fact that the relationship between HRH and independent factors may be non-linear and the linear regression model in this case may be insignificant. In available scientific literature we did not find examples of practical application of any health workforce projection models in Kazakhstan.

The purpose of this study was to consider the basic scenario for predicting the need for General Practitioners (GP) in Kazakhstan until 2030.

\section{Material and methods}

The basic workforce forecasting model is based on the stock-flow methodology and consists of supply and demand submodels. An integral part of modeling is the analysis of forecasting results and the development of actions that can prevent a possible imbalance in human resources. Stock-flow models were proposed by Godley and Cripps [12] and extended by Godley and Lavoie [13] and Kinsella et al. [14] for financial systems in macroeconomics. The methodology is based on the idea that everything should come from somewhere and go somewhere [15].

The model is designed to predict the supply and demand of GP in Kazakhstan for the period from 2019 to 2030 . The base year is 2018. The model uses variables that are the most accessible and most accurate at the present time and most significantly affect the state of the labor force in primary health care. Figure 1 shows the relationships between stocks and inflows and outflows over time.

Figure 1 - Stock-flow consistent model

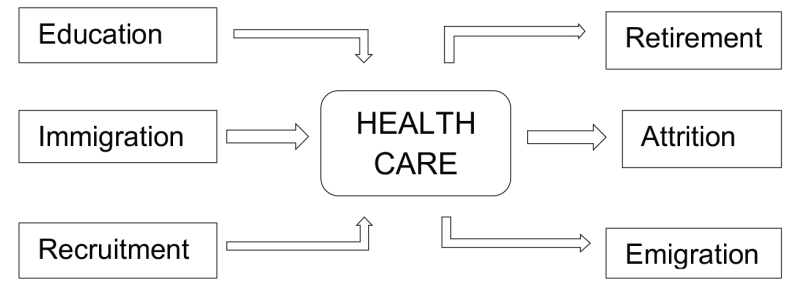

\section{Data collection}

The main challenge for implementing our workforce planning model was the availability and reality of data. Among the weaknesses of the human resources management system of the Republic, one can single out disparate HRH databases and inconsistency of HRH credentials with international standards [16]. Workforce information can be found in the reporting forms of Ministry of Health: "Medical organization Report", "Report on medical resource", as well as in the database "Personnel", on the portal of the Republican e-health center, in the department of science and human resources of Ministry of Health, in employment departments of medical universities. None of these sources is comprehensive. The parameters of the model were determined according the information provided to us by various government agencies regulating the health care of Kazakhstan. This information included data on health care professionals, on the need for medical care and on the training of doctors in the republic's universities. Table 1 details these sources and their content.

Table 1

Data sources

\begin{tabular}{|l|l|}
\hline Model parameter & Source \\
\hline $\begin{array}{l}\text { Number of doctors in primary } \\
\text { health care in 2014-2018 }\end{array}$ & $\begin{array}{l}\text { Republican Center for Health } \\
\text { Development }\end{array}$ \\
\hline $\begin{array}{l}\text { Amount of FTE per doctor in } \\
\text { 2014-2018 years }\end{array}$ & $\begin{array}{l}\text { Republican Center for Health } \\
\text { Development }\end{array}$ \\
\hline $\begin{array}{l}\text { Demographic developments in } \\
\text { 2018-2030 }\end{array}$ & $\begin{array}{l}\text { Ministry of Economy and Budget } \\
\text { Planning }\end{array}$ \\
\hline $\begin{array}{l}\text { New graduates (all medical } \\
\text { universities in Kazakhstan) }\end{array}$ & $\begin{array}{l}\text { Department of Science and Human } \\
\text { Resources of the Ministry of Health }\end{array}$ \\
\hline Recruitment & $\begin{array}{l}\text { Department of Science and Human } \\
\text { Resources of the Ministry of Health }\end{array}$ \\
\hline $\begin{array}{l}\text { Exits from the health workforce } \\
\text { due to retirement }\end{array}$ & $\begin{array}{l}\text { Department of Science and Human } \\
\text { Resources of the Ministry of Health }\end{array}$ \\
\hline $\begin{array}{l}\text { Exits from the health workforce } \\
\text { due to another reasons }\end{array}$ & $\begin{array}{l}\text { Department of Science and Human } \\
\text { Resources of the Ministry of Health }\end{array}$ \\
\hline
\end{tabular}

\section{Results \\ Current situation}

In Kazakhstan, the functioning model of primary health care inherited from the USSR the local principle of serving the population with the definition for each primary health care specialist of a clearly limited service area with a certain number of adults for the therapist and children for the pediatrician. According to standards, one local therapist is for 2200 adults and one pediatrician is for 900 children. In this well-built model, a new post of GP, taken from the experience of developed countries, has been introduced. In the future, the GP should become the main link in the primary health care system. He has the knowledge and skills to help with the most common diseases for all age groups. His team includes skilled secondary medical, social workers and other professionals required to deliver health services to a designated population. The GP is charged with serving the population in 2000 without dividing into age categories [17]. However, these standards are not binding and every health care facility has the right to adjust it annually.

A GP performing this standard and working 40 hours a week is assigned 1 Full Time Equivalent (FTE). Due to low wages and staff shortages, many GP take on additional workload (without increasing the number of hours) and receive additional payment due to vacant rates, so the amount of FTE per GP is more than 1 . 
In recent years, the number of doctors in the primary health care system of Kazakhstan has increased with an average growth rate of $6 \%$ (Table 2). Firstly, this was due to an increase in the population of the Republic (an average growth rate of $1.3 \%$ per year) and, secondly, to a decrease in the number of assigned population per doctor. If in 2014 the workload was 2054 population per 1FTE, then in 2018 it was already 1728. Over the years one FTE doctor accounted for 1858 people on average. Currently, the density of primary health care doctors in the republic is 57 per 100000 population.

Primary healthcare workforce in Kazakhstan

\begin{tabular}{|c|c|c|c|c|c|c|c|}
\hline & Population size & $\begin{array}{l}\text { Number of } \\
\text { doctors }\end{array}$ & $\begin{array}{l}\text { Density per } \\
100,000\end{array}$ & $\begin{array}{l}\text { Population per } \\
\text { doctor }\end{array}$ & $\begin{array}{l}\text { FTE } \\
\text { per doctor }\end{array}$ & $\begin{array}{l}\text { Population per } \\
\text { 1FTE }\end{array}$ & $\begin{array}{l}\text { Head counts } \\
\text { of FTE }\end{array}$ \\
\hline 2014 & 17267141 & 8240 & 48 & 2096 & 1,02 & 2054 & 8405 \\
\hline 2015 & 17503080 & 8805 & 50 & 1988 & 1,02 & 1949 & 8981 \\
\hline 2016 & 17735340 & 9492 & 54 & 1868 & 1,02 & 1832 & 9682 \\
\hline 2017 & 17962170 & 10279 & 57 & 1763 & 1,02 & 1728 & 10394 \\
\hline 2018 & 18182015 & 10314 & 57 & 1763 & 1,02 & 1728 & 10520 \\
\hline
\end{tabular}

\section{Demand}

In the baseline we project the demand for healthcare workers assuming that the same level of service (defined as attached population per GP) is provided for an increasing population. We used the projection for the population of Kazakhstan until 2030, compiled by the Ministry of Economy and Budget Planning of the Republic of Kazakhstan. Based on these data, the number of FTE was calculated as compared to 2018 (Table 3). According to these data, it is predicted that in Kazakhstan until 2030, the need for GP will increase at an average rate of $0.9 \%$.

\section{Outflow variables}

A part of the specialists is lost annually due to leaving associated with full or early retirement, emigration, death in service and other reasons (leaving work or the labor market). There are several challenges in outflow assessing. One of these problems is associated with finding information about the number of people who have left the profession.

To assess the various flows, we used data for the last four years, provided to us by the Department of Science and Human Resources of the Ministry of Health (Table 4).

Retirement. According to the Department of Human Resources and Science of the Ministry of Health of the Republic of Kazakhstan in recent years, from 2014 to 2017, approximately $1 \%$ of primary health care workers every year leave their occupation due to retirement. We assumed that this share would remain permanent in future years.

Emigration. Emigration, in our opinion, does not have a significant effect on attrition. According to the data from the Table 4 , it is approximately $0.1 \%$ of the total number of primary health care GP.

\begin{tabular}{|l|l|l|l|}
\hline Year & Population & $\begin{array}{l}\text { Growth rate } \\
\text { (comparing with 2018) }\end{array}$ & $\begin{array}{l}\text { Health care } \\
\text { demand (FTE) }\end{array}$ \\
\hline 2019 & 18393708 & 1,004 & 10879 \\
\hline 2020 & 18596568 & 1,015 & 10999 \\
\hline 2021 & 18790610 & 1,025 & 11107 \\
\hline 2022 & 18976379 & 1,036 & 11226 \\
\hline 2023 & 19154791 & 1,045 & 11324 \\
\hline 2024 & 19327060 & 1,055 & 11432 \\
\hline 2025 & 19494551 & 1,064 & 11530 \\
\hline 2026 & 19658707 & 1,073 & 11627 \\
\hline 2027 & 19821112 & 1,082 & 11725 \\
\hline 2028 & 19983452 & 1,091 & 11822 \\
\hline 2029 & 20147304 & 1,099 & 11909 \\
\hline 2030 & 20313981 & 1,109 & 12017 \\
\hline
\end{tabular}

Attrition for other reasons. Major reason to leave primary health care is decision to apply to different highly specializations and continue their studies in residency. The reasons can also be migration within the country, transfer from one medical facility to another, military service, transfer to another field of activity, maternity leave, illness and death. We did not single out any groups for reasons that lead to the fact that people leave their profession at different stages of life, and just used the available data on outflow rates. As can be seen from Table 4 for four years attrition in the whole of Kazakhstan averaged 15\% and this value was used in our model.

Deficits. The Ministry of Health estimates that the shortage of GP in primary health care is $3 \%$. We have calculated how many GP will be needed in the future to compensate for the output flows, as well as the deficit.

\begin{tabular}{|c|c|c|c|c|c|c|c|c|c|}
\hline & $\begin{array}{l}\text { Headcount at the } \\
\text { beginning of the year }\end{array}$ & $\begin{array}{l}\text { Recruitment } \\
\text { (without new graduates) }\end{array}$ & $\%$ & Emigration & $\%$ & Retirement & $\%$ & Attrition & $\%$ \\
\hline 2014 & 8240 & 1057 & 13 & 13 & 0,2 & 106 & 1 & 1190 & 14 \\
\hline 2015 & 8805 & 996 & 11 & 13 & 0,1 & 101 & 1 & 1344 & 15 \\
\hline 2016 & 9492 & 831 & 9 & 9 & 0,1 & 127 & 1 & 1187 & 13 \\
\hline 2017 & 10279 & 871 & 8 & 15 & 0,1 & 149 & 1 & 1632 & 16 \\
\hline Mean & & & 10 & & 0,1 & & 1 & & 15 \\
\hline
\end{tabular}




\section{Inflow variables}

Recruitment (without new graduates). These are newly recruited GP. Among them may be those who have moved to another place of residence or, for some reason, moved from one hospital to another. It can also be those who have completed military service, came from maternity leave, moved from related fields of medicine, or decided to return to medical practice after a break. According to our data they are $10 \%$.

Education. The main source of new health care workforce is the national medical education system. In Kazakhstan $80 \%$ of students study for free under state educational grants. The period of training of GP is 7 years: future doctors of 5 years are studying undergraduate degrees in General medicine and then 2 years of internship. The internship is preparing for several clinical specialties, including the specialty "general practitioner". The number of places allocated to each specialty, the university determines on its own, based on the needs of health care. Later part of the graduates of the specialty GP go to the residency or magistracy, the other part goes to work in primary health care (Figure 2).

Figure 2 - Medical education system in Kazakhstan

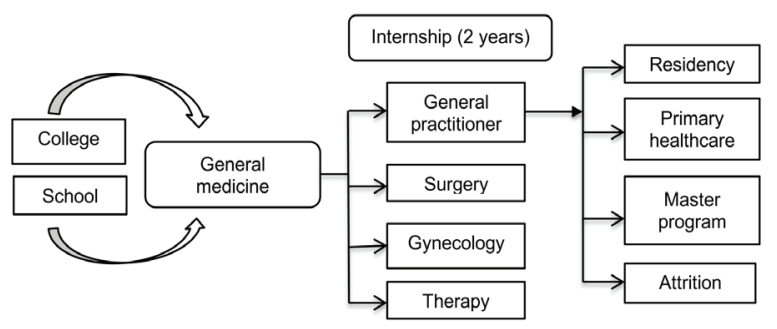

If in 2009-2014 the number of medical students was increased, then, as the shortage of medical workers was eliminating, from 2015 to 2018, the government reduced the number of grants allocated to medical specialties, including the specialty General Medicine (Table 5). In subsequent years, from 2019 to 2021 , according to a government decree, the number of grants will remain unchanged at 2,700.

According to the Departments of Employment of Medical Universities, about $30 \%$ of those entering the specialty "General Medicine" after completing the internship work in primary healthcare. In accordance with this, we accepted that in 20192021 each year 900 new GP graduates will enter the labor market, then, in 2022-2024, this number will decrease to 800 and further, in 2025-2030, to 700 GPs.

\section{Baseline projections}

Table 6 presents the algorithm for calculating elements of inflow and outflow. 2018 was adopted as the base year.

Similarly, supply and demand for the following years were calculated (Table 7). The table also presents the input and output flows, as well as the projected deficit or surplus of GP for each year until 2030.

In the baseline scenario we project the demand for GP assuming that the level of service provided to a growing population will remain unchanged. Such an indicator as the density of GP per population will not change. So, the total need for GP is determined based on the demand due to population growth and the demand for replacement (losses due to retirement, emigration, etc.). The population is projected to reach 20.3 million in 2030 .

\section{Discussion}

Baseline results should only be interpreted as a need for replenishment based solely on anticipated population growth, while maintaining a workload per GP. According to the proposed scenario, in some years of the forecast period, both an excess and a lack of a GP offer are possible. The largest surplus, 226 GP, is predicted in 2024. However, starting in 2027 their shortage is possible, with a peak of 339 GP in 2030 (Figure 3).

As noted above, after five years of study, students are assigned to a 2-year internship in four specialties, including the "General practitioner". The number of places is determined by the university itself in accordance with requests from regional

Figure 3 - General Practitioner forecasting

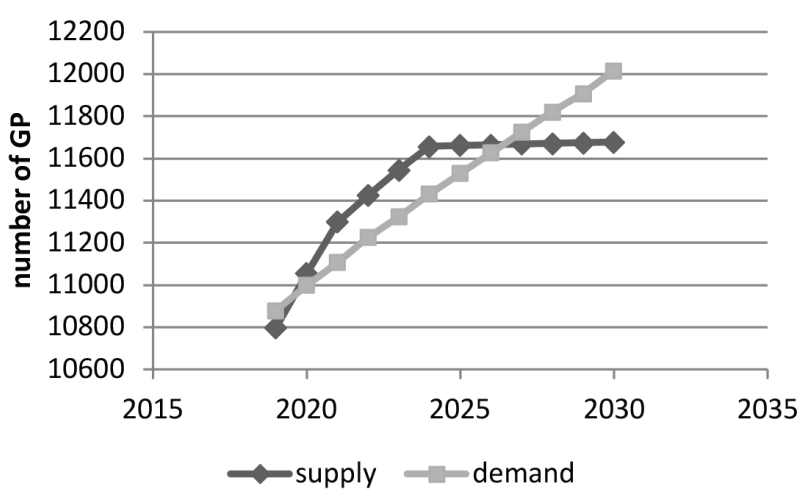

health departments. Today, graduates do not have problems with employment, since many regions are experiencing a deficit of primary health care workforce and offer various incentives for young professionals, so that up to $98 \%$ of new GP graduates find a job. However, the deficit of GP is gradually eliminated and, in accordance with this, the government reduces the number of grants for medical education. And we can expect decreasing number of GP in the labour market. But at the beginning of the 20 s, it will still have an effect on the admission of students in 2013-2017, which may lead to a workforce oversupply.

\begin{tabular}{|c|c|c|c|c|c|c|c|c|c|c|}
\hline & 2009 & 2010 & 2011 & 2012 & 2013 & 2014 & 2015 & 2016 & 2017 & 2018 \\
\hline $\begin{array}{l}\text { Government grants for medical education } \\
\text { (total) }\end{array}$ & 3500 & 3600 & 3600 & 3700 & 3700 & 3700 & 3000 & 3000 & 3150 & 2700 \\
\hline $\begin{array}{l}\text { Government grants for "General medicine" } \\
\text { (undergraduate program) }\end{array}$ & 3263 & 3356 & 3356 & 3433 & 3434 & 3438 & 2528 & 2433 & 2700 & 2152 \\
\hline Internship «General practitioner» output & No data & No data & No data & No data & No data & 938 & 1047 & 1547 & 2060 & 2103 \\
\hline $\begin{array}{l}\text { From them entered the labour market } \\
\text { (primary healthcare) }\end{array}$ & No data & No data & No data & No data & No data & 476 & 664 & 980 & 1128 & \\
\hline
\end{tabular}




\begin{tabular}{|c|c|}
\hline Current available supplay & $\begin{array}{l}\text { For } 2018 \text {, the total number of available GP was } 10314 \text {. } \\
\text { On average GP worked 1,02 FTE. With these numbers, the total available supply in FTE for } 2018 \text { can be calculated as } \\
10520 \text { FTE. }\end{array}$ \\
\hline Current required supply & $\begin{array}{l}\text { According to the Ministry of Health in } 2018 \text { the deficits between health-care demand and available supply was } 3 \% \text {. } \\
\text { Based on the total available supply in } 2018 \text { of } 10520 \text { FTE and the gap of 3\%, the required health-care is estimated at } \\
10836 \text { FTE }\end{array}$ \\
\hline Outflow & $\begin{array}{l}\text { Outflow due to retirement is calculated as } 1 \% \text { of } 10314 \text { and equal } 103 \mathrm{GP} \\
\text { Emigration is estimated as } 0,1 \%(10 \mathrm{GP}) \\
\text { Attrition is } 15 \% \text { of } 10314(1547 \mathrm{GP}) \\
\text { Total recruitment requirement } 1661 \mathrm{GP}\end{array}$ \\
\hline Inflow & $\begin{array}{l}\text { New graduates - } 900 \mathrm{GP} \\
\text { Recruitment }(10 \% \text { of } 10314)-1031 \mathrm{GP} \\
\text { Total: } 1931 \mathrm{GP}\end{array}$ \\
\hline Future available supply & $\begin{array}{l}\text { The number of GP available in } 2019 \text { is calculated using the number of GP in the baseline year (2018) and the outflow } \\
\text { and inflow of GP in the alternate years }(10314-1661+1931=10585) \\
\text { FTE in } 2019 \text { is defined by multiplying the projected number of GP available (element } 9 \text { ) with the projected percentage of } \\
\text { FTE per doctor }(10585 * 1,02=10797)\end{array}$ \\
\hline Future required supply & $\begin{array}{l}\text { For } 2019 \text {, it has been projected that the total required supply is } 10879 \text {, based on the required supply in } 2018 \text { (10836 } \\
\text { FTE, including unmet demand) and demographic developments until } 2019 \text { (which will increase demand by } 0,4 \% \text { ) }\end{array}$ \\
\hline Gap & If the baseline model is applied, there will be an excess demand in 2019 of $10879-10797=83 \mathrm{FTE}$. \\
\hline
\end{tabular}

Table 7 Forecasting results

\begin{tabular}{|l|l|l|l|l|l|l|l|l|l|}
\hline & Retirement & Immigration & Attrition & Recruitment & $\begin{array}{l}\text { New } \\
\text { graduates }\end{array}$ & $\begin{array}{l}\text { GPs } \\
\text { supply }\end{array}$ & $\begin{array}{l}\text { FTE } \\
\text { supply }\end{array}$ & $\begin{array}{l}\text { Demand } \\
\text { supply }\end{array}$ & \begin{tabular}{l} 
Gap* \\
\hline 2019
\end{tabular} \\
\hline 2020 & 103 & 10 & 1547 & 1031 & 900 & 10585 & 10797 & 10879 & 82 \\
\hline 2021 & 108 & 11 & 1588 & 1059 & 900 & 10839 & 11056 & 10999 & -57 \\
\hline 2022 & 111 & 11 & 1626 & 1084 & 900 & 11078 & 11300 & 11107 & -193 \\
\hline 2023 & 112 & 11 & 1662 & 1108 & 800 & 11202 & 11426 & 11226 & -200 \\
\hline 2024 & 113 & 11 & 1698 & 1132 & 800 & 11429 & 11658 & 11432 & -226 \\
\hline 2025 & 114 & 11 & 1714 & 1143 & 700 & 11433 & 11662 & 11530 & -132 \\
\hline 2026 & 114 & 11 & 1715 & 1143 & 700 & 11436 & 11665 & 11627 & -38 \\
\hline 2027 & 114 & 11 & 1715 & 1144 & 700 & 11440 & 11669 & 11725 \\
\hline 2028 & 114 & 11 & 1716 & 1144 & 700 & 11443 & 11672 & 11822 \\
\hline 2029 & 114 & 11 & 1716 & 1144 & 700 & 11446 & 11675 & 11909 \\
\hline 2030 & 114 & 11 & 1717 & 1145 & 700 & 11449 & 11678 & 12017 \\
\hline * A positive gap indicates excess demand (shortage of healthcare workers); a negative gap, excess supply. & & & \\
\hline
\end{tabular}

We do not know anything about the government's plans in medical education after 2021. Therefore, we stopped on 800 and 700 new graduates of GP in subsequent years. This scenario leads to the fact that inflow does not cover the increasing needs of primary health care associated with population growth. In this case, our forecast is the basis for medical schools to adjust the number of GP students in internship, seeking a balance of supply and demand.

Another element that has a significant impact on human resource planning is staff turnover. It is associated with the flow of specialists from rural to urban areas and with low wages in primary health care in comparison with other sectors of health care, as well as with the transition from the public to the private sector. It is expected that greater stimulation in the primary health care sector will contribute to solving the problem of workforce.

In this study, we developed a quantitative supply and demand model for GP in Kazakhstan. The model was used to predict the additional recruitment of GP due to the expected population growth, without changing other influencing factors such as socio-economic, epidemiological and others. The model allowed us to assess the ability of the medical education system to meet this basic requirement.

We understand that the base model is only the first step in forecasting human resources in health care. It has a number of drawbacks, since we generally assume the "status quo" on the supply side and demand side for all other non-demographic variables. We also made a cautious assumption that the number of new GP will be reduced in accordance with the plans of the Ministry of Health. In addition, the model assumes that some components of demand remain unchanged: for example, the use of health care, the provision of health services, or an increase in health care costs. Now it is necessary to go further and try to assess future changes in healthcare: an increase in demand for medical services from every member of society, an increase in medical services from medical institutions, changes related to the age and gender structure of the population. Also, it is necessary to reflect possible future changes in the health status of the population using epidemiological data, trends in socio-cultural development.

Disclosures: There is no conflict of interest for all authors.

Acknowledgements: The authors wish to thank the study participants for their contribution to the research, as well as current and past investigators and staff.

Funding: None. 


\section{References}

1. World Health Organization. Global strategy on human resources for health: workforce 2030. Geneva: WHO; 2015. 25 p.

2. Minimum Planning data requirements for health Workforce Planning. Joint Action Health Workforce Planning and Forecasting D.051 Release 1 available at http://euhwforce.weebly.com/results.html

3. Roberfroid D, Leonard C, Stordeur S. Physician supply forecast: better than peering in a crystal ball. Human Resources for Health. 2009; 7(10):1-13. https://doi.org/10.1186/1478-4491-7-10

4. Hall TL. Demand and supply. In: Hall TL, Mejia A., editors. Health manpower planning: principles, methods, issues. Geneva: WHO. 1978; 57-116.

5. Models and tools for health planning and projections. Geneva: WHO; 2010. $19 \mathrm{p}$.

6. McQuide P, Stevens J, Settle D. An overview of human resources for health (HRH) projection models: Technical brief 12. Chapel Hill: The Capacity Project; 2008; 4.

7. Dreesch N. et al. An approach to estimating human resource requirements to achieve the Millennium Development Goals. Health Policy and Planning. 2005; 20(5):267-276. https://doi.org/10.1093/heapol/czi036

8. Malgieri A, Michelutti P, Van Hoegaerden M. Handbook on Health Workforce Planning Methodologies across EU countries. Slovakia: Joint Action Health Workforce Programming \& Forecasting, Funded by the Health Programme of the European Union; 2015

9. Al-Sawai A, Al-Shishtawy MM. Health Workforce Planning: An overview and suggested approach in Oman. Sultan Qaboos University medical journal. 2015; 15(1):27-33.

10. Roberfroid D, Leonard C, Stordeur S. Physician supply forecast: better than peering in a crystal ball? Human Resources for Health 2009; 7:10. https://doi.org/10.1186/1478-4491-7-10

11. Koikov VV, Turumbetova TB, Zhashkenova NS. et al. Methods of planning and forecasting human resources health care in terms of compulsory social health insurance. Astana: Republican Center for Healthcare Development; 2016 http://www.rcrz.kz/docs/nauka/ mr4.pdf

12. Godley W, Cripps F. Macroeconomics. London: Fontana. 1983; 200.

13. Godley W, Lavoie M. Monetary Economics: an integrated approach to credit, money, income, production and wealth. London: PalgraveMac Millan. 2007; 530.

14. Kinsella S, Greiff M, Nell EJ. Income distribution in a stock-flow consistent model with education and technological change. Eastern Economic Journal. 2011; 37(1):134-149. https://doi.org/10.1057/eej.2010.31

15. Copeland MA. Social accounting for money flows. The Accounting Review 1949; 24(3):254-264.

16. Ministerstvo zdravoohranenija Respubliki Kazahstan. Nacionalnaja politika upravlenija kadrovymi resursami zdravoohranenija, Astana, 2017, 21 p. http://www.rcrz.kz/files/nauka/Национальная\%20политика\%20управления\%20КР3.pdf

17. The demographic forecast of the Republic of Kazakhstan: main trends, challenges, practical recommendations. Order of the Minister of Health of the Republic of Kazakhstan; 2010.https://www.akorda.kz/upload/nac_komissiya_po_delam_zhenshin/Демографическая\%20 политика/4.2\%20pyc.pdf 